10.4274/tjps.23500

Research Article

\title{
Repurposing of tamoxifen against the oral bacteria
}

\section{Repurposing of tamoxifen against the oral bacteria}

Ali Abdul Hussein S. AL-Janabi ,Dept. of Microbiology, College of Medicine, University of

Repurposing of tamoxifen against the oral bacteria Karbala, Karbala-Iraq

\section{Abstract}

Objective: Tamoxifen (TAM), which is used for the treatment of breast cancer, has another function as an antimicrobial agent. Antibacterial action of TAM against the bacteria of the human oral cavity was investigated.

Materials and Methods: Bacteria of the human oral cavity were isolated from the healthy individuals. Different concentrations of TAM were tested against isolated bacteria. Bactericidal and bacteriostatic effects of TAM were also determined.

Results: Out of 23 isolated bacteria, more Gram-positive bacteria were highly susceptible to low concentration of TAM than Gram-negative. Kytococcus sedentarius, as one Grampositive, and Pseudomonas stutzeri, as one Gram-negative, needed high MIC value of TAM $(2.5 \mathrm{mg} / \mathrm{ml})$ to inhibit by its bacteriostatic action. Resistance to TAM was also observed in three strains of Gram-positive and in four strains of Gram-negative bacteria.

Conclusion: Tamoxifen has a potential antibacterial effect against the bacteria of the oral cavity, especially against Gram-positive. This effect is mostly bacteriostatic. Bacteriaresistance toward TAM was also found.

Key words: bacteria, oral cavity, tamoxifen, Gram-positive, Gram-negative

Ali Abdul Hussein S. AL-Janabi,Dept. of Microbiology, College of Medicine, University of Karbala, Karbala-Iraq

07811411260

0000-0002-2479-3282

Email: aljanabibio@yahoo.com

01.10 .2019

12.12.2019

soyut

Amaç: Meme kanserinin tedavisinde kullanılan Tamoksifen (TAM), antimikrobiyal bir ajan olarak başka bir işleve sahiptir. TAM'ın insan ağız boşluğunun bakterilerine karşı

antibakteriyel etkisi araştırılmıştır. 
Gereç ve Yöntem: İnsan ağız boşluğu bakterileri sağlıklı bireylerden izole edildi. İzole edilen bakterilere karşı farklı konsantrasyonlarda TAM test edildi. TAM'ın bakterisidal ve bakteriyostatik etkileri de belirlenmiştir.

Bulgular: İzole edilen 23 bakteriden, Gram pozitif bakterilerin Gram negatifine göre düşük TAM konsantrasyonuna karşı çok hassas olduğu görülmüştür. Bir Gram pozitif olarak Kytococcus sedanter ve bir Gram negatif olarak Pseudomonas stutzeri, bakteriyostatik etkisiyle inhibe etmek için yüksek TAM değeri $(2,5 \mathrm{mg} / \mathrm{ml})$ gerektirmiş̧tir. TAM'ye direnç ayrıca üç Gram-pozitif suşta ve dört Gram-negatif bakteri suşunda gözlemlenmiştir.

Sonuç: Tamoksifenin ağız boşluğundaki bakterilere, özellikle Gram-pozitiflere karşı potansiyel bir antibakteriyel etkisi vardır. Bu etki çoğunlukla bakteriyostatiktir. TAM'a bakteri direnci de bulundu.

Anahtar kelimeler: bakteri, ağız boşluğu, tamoksifen, Gram pozitif, Gram negati

\section{Introduction}

Tamoxifen (TAM) as one member of selective estrogen receptor modulators (SERMs) is mainly used for treatment and prevention of estrogen positive breast cancer [1-2]. It was first introduced by AstraZeneca of UK to become a more effective therapy for estrogen positive breast cancer in women of Pakistan and Australia [3]. After more than 40 years, TAM is considered a golden drug for treatment of breast cancer and to extending the lives of approximately 500,000 women every year worldwide [3-5]. The TAM usage as a chemopreventive is another approach approved by the FDA to protect women from breast cancer for at least 5 years $[4,6]$. It also found to have an ability to reduce the mortality due to coronary heart disease (CHD) based on two years of postoperative application [7].

The potential antimicrobial activities of TAM against various pathogenic organisms make this drug repurposing toward another approach of treatment [8]. Direct and indirect antibacterial activity of TAM has been confirmed against different types of bacteria. It is showed direct inhibitory action on the growth of Staphylococcus aureus and methicillinresistant S. aureus (MRSA) strains [9] and also against Mycobacterium tuberculosis [10-11]. The growth of Enterococcus faecium and its pathogenesis was found to be reduced by TAM when applied in a Galleria mellonella infection model [12]. Meanwhile, indirect antibacterial action of TAM was observed when it enhanced the activity of immune cells represented by neutrophils against various pathogenic bacteria such as MRSA, Pseudomonas

aeruginosa and Escherichia coli through agonist activity of the G protein-coupled estrogen receptor GPER [13]. Moreover, antibacterial action of standard antibiotics such as polymyxin $B$ is also increased against various bacteria after combination with TAM [14].

The treatment of breast cancer by TAM usually takes a long period that could reach to 5 years [3], so the normal bacterial flora of the human body, such as in the oral cavity, could be affected by the potential antibacterial activity of TAM. Thus, in vitro antibacterial activity of TAM against the oral flora of the human body was investigated. 


\section{Materials and Methods}

\section{Chemicals}

Tamoxifen citrate was purchased from Ebewe Pharma, Austria. Mueller-Hinton agar (MHA) and Mueller-Hinton broth (MHB) were purchased from HiMedia, India. Cefotaxime was purchased from SDI, Samarra, Iraq.

\section{Isolation of bacteria}

Swab samples were collected from the oral cavity of the volunteer healthy individuals by sterilized cotton swabs. Collected samples were cultured on blood agar and MacConkey agar (HiMedia, India). Inoculated media were incubated at $37^{\circ} \mathrm{C}$ for 24 hours for growing suspected bacteria. Diagnosis of the isolated bacteria was performed by Vitek $\mathbb{R}$ system using Vitek ${ }^{\circledR} 2$ YST ID diagnostic cards for Gram-positive and Gram-negative bacteria (BioMérieux, France).

\section{Determination of minimum inhibitory concentration (MIC) of TAM}

The MIC of tamoxifen was determined based on the methods of dilution antimicrobial susceptibility tests for bacteria that grow aerobically as mentioned by CLSI-M07-A10 (2015) [15]. A broth culture of isolated bacteria was prepared by inoculum selected bacteria in Mueller-Hinton broth (MHB) and incubated at $37^{\circ} \mathrm{C}$ for 24 hours. The turbidity of growing bacterial cells was adjusted with $0.5 \mathrm{McFarland}$ standards to contain approximately $1 \times 10^{8}$ $\mathrm{cfu} / \mathrm{ml}$. Serial concentrations of TAM $(5,2.5,1.25$, and $0.625 \mathrm{mg} / \mathrm{ml})$ were prepared from a stock solution $(10 \mathrm{mg} / \mathrm{ml})$. Plastic microdilution plates (96 well) were used to determine the MIC value of TAM. Each well of the plate received $50 \mu \mathrm{l}$ from standard count of each bacteria suspension and $100 \mu \mathrm{l}$ from MHB, followed by adding $50 \mu 1$ of specific concentration of TAM. Several controls were used within a microdilution plate, including MHB with bacteria only, MHB without bacteria, and MHB with TAM only. Cefotaxime was also used as control antibiotic in different concentrations $(0.5,1,2,3$, and $4 \mu \mathrm{g} / \mathrm{ml})$. The inoculated plate was incubated at $37 \mathrm{C}$ for 24 hours. The results were visually read as the presence or absence of bacteria growth.

Bactericides and bacteriostatic effect of TAM was determined by re-culturing of growth inhibited bacteria from the microdilution plate on Mueller-Hinton agar and incubated at $37^{\circ} \mathrm{C}$ for 24 hours. Growth of inhibited bacteria indicated for bacteriostatic action, while absence of growth showed bactericidal effects.

\section{Results}

A total of 23 isolated strains of bacteria were diagnosed after culturing of swab samples from the oral cavity. There were 13 strains of Gram-positive and 10 strains of Gram-negative bacteria. Although more concentrations of TAM were required compared with cefotaxime, most of the Gram-positive bacteria were highly susceptible to low concentration of TAM than the Gram-negative bacteria. They also inhibited in less MIC value of TAM compared with cefotaxime (1-2 than Kytococcus sedentarius as one Gram-positive and Pseudomonas stutzeri as one Gram-negative needed high concentrations of TAM to inhibit (MIC: 2.5 $\mathrm{mg} / \mathrm{ml}$ ) and the effect of TAM was determined in these two types of bacteria as bacteriostatic action (Table 1 and 2).

The effective low concentrations of TAM on susceptible bacteria which showed MIC at $0.625 \mathrm{mg} / \mathrm{ml}$ was mostly determined as bacteriostatic action. This bacteriostatic action was clearly shown in five isolated strains of Gram-positive and in two strains of Gram-negative bacteria, while TAM showed bactericidal action against three strains of Gram-positive and one strain of Gram-negative at the same concentration (Table 1 and 2). 
Resistance to TAM was observed in three strains of Gram-positive bacteria, including Granulicatella elegans, Kocuria kristinae and Kocuria varians and in four strains of Gramnegative bacteria, including Acinetobacter haemolyticus, E. coli, Enterobacter cloacae and Klebsiella pneumonia (Table 1 and 2).

\section{Discussion}

Tamoxifen is an effective drug for the treatment of breast cancer in women and men [3-4]. Based on clinical trial study around the world, TAM can reduce the incidence of breast cancer by $50 \%$ in high-risk pre- and postmenopausal women [6]. It also used as adjuvant therapy with more than 5 years efficacy for postmenopausal, node-positive, and estrogen 0 progesterone receptor positive women since the mid-1980s [3,6]. Thus, TAM is commonl used by more than 7 million patients in a year, saving the lives of approximately 500,000 women $[3-4,6]$. In addition to the antagonist binding of TAM with estrogen receptor to prevent the development of breast cancer $[4,6]$, it also has another mechanism to prevent this type of cancer through stimulating production of TGF-calmodulin and protein kinase $C$, and also by blocking of the angiogenesis process via lowering of IGF-1 and TGF production [16]. Resistance of bacteria to the most common antibacterial agents has increased progressively within recent times due to massive over-use of this type of agents [17]. Miss use and overprescription of antibacterial agents is considered the most important factor contributing to the rise of resistant bacterial strains for such type of agents [18]. The bacteria of the oral cavity have also developed drug-resistance toward many common types of antibiotic due to genetic changes in their genomic structure [19]. The resistance of the oral bacteria to erythromycin due to the activity of mef and $\operatorname{erm}(\mathrm{B})$ genes is one example of such antibiotic-resistance [20]. However, the list of antibiotics has hardly changed in 4 decades and most of the pharmaceutical companies left the antibiotic field cue to the absence of a new class of antibacterial agents [17]. Thus, antibiotic-resistance is becoming one of the modern crises and the time has come for a global commitment to develop new antibacterial drugs $[17,21]$. Repurposing of existing drugs can be introduced as one solution to resolve the limited number of antimicrobial agents and for enhancement of the treatment of most severe bacterial and fungal infections [22]. The repurposing process is usually applied to discovering a new therapeutic action of a specific drug to add to its previously known usage [8]. Tamoxifen is one of those drugs based on many studies which have proved that TAM has a potential antimicrobial effect through introducing promising data to repurpose of its use from anticancer drug into antimicrobial agent $[9-12,23]$. Low side effect profile and cheap price are other important characters that could encourage continued usage of TAM for treatment of cancer and microbial infections [6].

Out of 23 strains of the ral bacteria isolated in this study, 19 types revealed susceptibility to TAM with variable MIC values. Low concentration of TAM $(7.1 \mu \mathrm{g} / \mathrm{ml})$ exhibited moderate antibacterial effect against Mycobacterium tuberculosis [23], while a high concentration of it (MIC50: 5-10 mg/ml) is required to suppress its growth [12]. However, drug-sensitive strains of $M$. tuberculosis could be inhibited by low concentrations of TAM $(3.125-6.25 \mu \mathrm{g} / \mathrm{ml})$ compared with drug-resistance strains $(6.25$ to $12.5 \mu \mathrm{g} / \mathrm{ml})$ [10]. Antibacterial effects of TAM were also recorded against various other types of bacteria such as Enterococcus faecium and Staphylococcus aureus $[9,11]$ and also against more drug-resistant bacterial strains such as MRSA and M. tuberculosis [9-10]. Chemical derivatives of TAM have also shown potent antibacterial action. 4-hydroxytamoxifen, a metabolic derivative of TAM, revealed inhibitory action against $M$. tuberculosis with $\mathrm{MIC}_{50}$ value at $5-10 \mathrm{mg} / \mathrm{ml}$ [12]. Newly synthesized triaryl butane, which is an analogue of TAM, exhibited antibacterial activity against Gram-positive and Gram-negative food-borne pathogens, including Listeria monocytogenes, Listeria ivanovii, Enterococcus faecalis, Staphylococcus aureus and E. coli [24]. Triphenylethylene, which is considered a backbone of TAM, has also shown 
antibacterial activity against various types of pathogens including bacteria [8]. Otherwise, TAM was shown to have synergistic action with many known antibiotics to make them more effective against pathogenic bacteria as with polymyxin B against the polymyxin-resistant Pseudomonas aeruginosa, Klebsiella pneumoniae, and Acinetobacter baumannii [14, 25], and the three first-line (rifampin, isoniazid, and ethambutol) against $M$. tuberculosis [12]. The activity of chitosan against E. coli and Staphylococcus spp. was increased in the presence of TAM when they were prepared in nano-fiber PCL structure [26]. Moreover, TAM can play a role to increase the defense ability of the immune cells. This is well proven when the bactericidal activity of neutrophils is increased by TAM against various bacteria such as MRSA, $P$. aeruginosa and E. coli, and it can also enhance the bacterial clearance by this immune cell with 2.4-4.2 log reductions in bacterial counts in several types of tissue sampies [13]. Intracellular TB in macrophages also decreased after treatment with TAM in a dosedependent manner [10].

The results of this study have shown that Gram-positive bacteria are more susceptibie to TAM than Gram-negative bacteria. The resistance rate in Gram-negative bacteria was also found higher (36-73\%) toward many antibiotics than in Gram-positive [27]. Generally, resistance of Gram-negative bacteria is clearly identified toward various types of antibiotic due to its cell wall components which make them a formidable barrier against any dangerous materials [28]. Inhibition of function of the bacterial cell membrane is the proposed mechanism of TAM action against bacteria [23-24, 29]. This type of antibacterial action is mostly related to the hydrophobicity of TAM due to the presence of alkyl groups attached to the amino group in its structure [9]. Ultrastructural alterations in the components of the cell membrane of Bacillus stearothermophilus which lead to bacterial cell killing after treatment with TAM are evidence that TAM is a membrane-active drug [29]. This type of alteration which leads to high $\mathrm{K}^{+}$and $\mathrm{Na}^{+}$efflux from bacterial cells and causes severe damage in the inner and outer membrane is also recognized after treatment of E. coli and Listeria ivanovii with an analogue of tamoxifen (triaryl butane)[24]. The mitochondrial membrane of $M$. tuberculosis was also observed collapsing by the ionic protonophore uncouplers of TAM and its lipophilic nature [23].

Seven of the present isolated bacteria, including three types of Gram-positive and four types of Gram-negative showed resistance to TAM. This resistance may related to the modification of the lipid or protein composition of the outer membrane of bacterial cells as observed in most of antibiotic-resistant bacteria [28]. Other membrane modifications may include changing in the action of efflux pumps, expression of various drug deactivating agents, and proteolytic degradation [30].

Acinetobacter haemolyticus as one of four members of Gram-negative bacteria that was resistant to TAM, is also recorded to have resistance against other antibiotics. This bacterium which usually causes nosocomial infections and is frequently isolated from the ICU of the hospitals is emerging to be one of the bacteria-resistant to most of antimicrobial agents [31]. Is olates of A. haemolyticus from immunocompromised patients revealed a high level of resistance toward a wide range of antibiotics, including ampicillin-sulbactam, ampicillin, aztreonam, cefuroxime, and ceftazidime [32]. This resistance was also observed among isolated strains from ICU patients toward ciprofloxacin, cefepime, ceftazidime, piperacillin, and amikacin [31, 33]. Like clinical isolates, A. haemolyticus isolated from the natural environment also showed resistance to antibiotics such as cefotaxime and ceftazidime [34]. However, resistance of A. haemolyticus is mainly dependent on its acquisition of betalactamase and cephalosporinase enzymes, while resistance to quinolone is related to the mutations in gyrA and/or parC genes [35]. 
A second Gram-negative bacterium resistant to TAM was E. coli. This type of bacterium is usually sensitive to almost all relevant antibiotics, but it also has the ability to acquire resistance genes from other species of bacteria through horizontal gene transfer [36]. Another source of multiple- antibiotic- resistance may result from change in amino acids of mar locus regulator (MarR) or mutation in operator-promoter region marO of the bacterium [37]. A total of $137 \mathrm{E}$. coli isolates from cases of urinary tract infection exhibited high resistance (51.1\% to $94.3 \%$ ) to ten types of antibiotic [38], while 17 nonpathogenic E. coli strains from different sources revealed multiple-antibiotic-resistance due to the genes carried by class 1 and class 2 integrons [37]. However, transfer of resistance genes acquired by $E$. coli could result from plasmids and from other mobile genetic elements, such as transposons and gene cassettes in class 1 and class 2 integrons [36].

Enterobacter cloacae complex (ECC), which contains common nosocomial bacteria that have the ability to cause various types of infection [39], exhibited resistance to TAM based on the results of this current study. The greatest antibiotic resistance by E. cloacae was to penicilin, cephalosporins (cefotaxime, ceftazidime, ceftriaxone), aminoglycosides, colistin and fluoroquinolones [40-41]. An emerging resistance of ECC to a new generation of carbapenems was also recorded [39]. Pathogenic strains of E. cloacae that caused bacteremia were found to be resistant to cephalothin and ampicillin and a smaller number resistant to aminoglycosides [42]. However, this bacterium becomes resistant by acquiring resistance genes just likes other members of Gram-negative bacteria [39].

Klebsiella pneumoniae, which causes various nosocomial infections, sepsis in neonates and bacteremia [43-44], is another bacterium of Gram-negative group that showed resistance to TAM. Such resistance was also recorded against a wide range of antibiotics as shown by a study from 1998 to 2010 in USA [45]. The emergence of such types of multidrug-resistant bacteria have been increasing nowadays due to their production of extended-spectrum betalactamases [43] and a mutation in a $m g r B$ regulatory gene which lead to resistance to colistin [46].

The current results also exhibited resistance of three isolates of Gram-positive bacteria to TAM, including Granulicatella elegans, Kocuria kristinae and Kocuria varians. G. elegans which is related to nutritionally variant streptococci (NVS), is usually found as one of the oral flora with an ability to cause infections and endocarditis under some conditions [47-48]. It is considered the most sensitive species to most antibiotics in comparison to other species of its genus, especially G. adiacens [49-50]. Resistance of G. elegans to macrolide and beta-lactam antibiotics was recently noticed due to the presence of erm and mef genes [47, 49, 51]. This resistance could be increased in case of biofilm formation by this bacterium [52]. Our results also showed that two isolates of Kocuria spp., including K. kristinae and $K$. varians, were resistant to TAM. This Gram-positive cocci bacterium is mostly nonpathogenic, and it mostly causes infection in immunocompromised patients such as with cancer diseases [53-54]. Antibiotic-resistance is hardly recognized in this bacterium due to very limited available data [53]. Thus, the absence of useful guidelines for determining the antibiotic-resistance of Kocuria spp. makes the susceptibility test necessary according to the Staphylococcus guidelines [54]. However, K. kristinae found to be more resistant to antibiotics than K. varians. All isolates of $K$. varians from endophthalmitis patients were found sensitive to all tested antibiotics, while $K$. kristinae shown resistance to amikacin and cefazolin [55]. Other isolates of $K$. kristinae from patients with UTI, immunosuppressive conditions, and cancer diseases also exhibited resistance to a wide range of antibiotics [5657]. Meanwhile, all isolates of $K$. varians from periodontitis and brain abscess exhibited sensitivity to all tested antibiotics [58-59].

\section{Conclusion}


The antibacterial action of TAM was clearly observed against oral bacteria, especially against Gram-positive bacteria. The action was mostly a bacteriostatic effect. The repurposing of TAM from cancer therapy into antimicrobial treatment could be encouraged by many factors such as that TAM is a cheap drug with few adverse effects. Although some bacteria show resistance, most known virulent species of isolated bacteria were found to be sensitive to TAM. This will give a promising view to use TAM in the treatment of infections caused by such types of bacteria.

\section{References}

1- Osborne CK. Tamoxifen in the treatment of breast cancer. Drug Therapy. 1998, 339: 1609-1618.

2- $\quad$ Bekele RT, Venkatraman G, Liu R, Tang X, Benesch MG, Mackey JR, Godbout R, Curtis JM, McMullen TP, Brindley DN. Oxidative stress contributes to the tamoxifeninduced killing of breast cancer cells: implications for tamoxifen therapy and resistance. Scientific Reports. 2016, 6:1-17.

3- $\quad$ Shahbaz K. Tamoxifen: Pharmacokinetics and pharacodynamic. Pharm Res. 2017, $1: 1-8$.

4- Jordan VC. Tamoxifen: a most unlikely pioneering medicine. Nature Reviews Drug Discovery. 2003, 2:215-213.

5- Bogush TA, Polezhaev BB, Mamuchey IA, Bogush EA, Polotsky BE, Tjulandin SA, Ryabov AB. Tamoxifen never ceases to amaze: New findings on non-estrogen receptor molecular targets and mediated effects. Cancer Invest. 2018, 36:211-220.

6- Jordan VC. Tamoxifen. Encyclopedia of Cancer. 2011 ed. Editor: Manfred Schwab, https://doi.org/1 0.1007/978-3-642-16483-5 5664.

7- Rosell J. Long-term effects of adjuvant tamoxifen treatment on cardiovascular disease and cancer. Linköping University Medical Dissertations No. 1430. Linköping University, Faculty of Health Sciences, Department of Clinical and Experimental Medicine, Division of Clinical Sciences, Oncology, Sweden. 2014.

8- Montoya MC, Krysan DJ. Repurposing estrogen receptor antagonists for the treatment of nfectious disease. mBio. 2018, 9:1-10. https://doi.org/10.1128/mBio.02272-18.

Levinson NS. Towards the elucidation of the mechanism of the antibiotic activity of tamoxifen. MS dissertation in Chemistry, College of Science. Georgia Institute of Technology. 2017. https://smartech.gatech.edu/bitstream/handle/1853/58251/LEVINSONTHESIS-2017.pdf. 
10- Jang WS, Kim S, Podder B, Jyoti A, Nam K, Lee B, Song H. Anti-mycobacterial activity of tamoxifen against drug-resistant and intra-macrophage Mycobacterium tuberculosis. J Microbiol Biotechnol. 2015, 25:946-950.

11- Chen F, Liao Y, Huang J, Lin C, Chen Y, Dou H, Hsiung CA. Pros and cons of the tuberculosis drugome approach-an empirical analysis. PLoS One, 2014, 9:1-9.

Doi:10.1371/journal.pone.0100829.

12- Jacobs AC, DiDone L, Jobson J, Sofia MK, Krysan D, Dunman PM. Adenylate kinase release as a high-throughput-screening-compatible reporter of bacterial lysis for identification of antibacterial agents. Antimicrobial Agent and Chemotherapy. 2013, 57:26 36.

13- Flores R, Insel PA, Nizet V, Corriden R. Enhancement of neutrophil antimicrobial activity by the breast cancer drug tamoxifen. FASEB Journal. 2016,30.969.14. https://www.fasebj.org/doi/abs/10.1096/fasebj.30.1_supplement.969.14.

14- Hussein M, Han M, Zhu Y, Schneider-Futschik EK, Hu X, Zhou QT, Lin Y, Anderson D, Creek DJ, Hoyer D, Li J, Velkov T. Mechanistic insights from global metabolomics studies into synergistic bactericidal effect of a polymyxin B combination with tamoxifen against cystic fibrosis MDR Pseudomonas aeruginosa. Computational and Structural Biotechnology Journal. 2018, 16:587-599.

15- $\quad$ Clinical and Laboratory Standards Institute

(CLSI). Methods for dilution antimicrobial susceptibility tests for bacteria that grow aerobically: Approved standard tenth edition. Document M07-A10. Wayne. Pennsylvania, 2015, 29(17).

16- Karn A, Jha AK, Shrestha S, Acharya B, Poudel S, Bhandari RB. Tamoxifen for breast cancer. J Nepal Med Assoc. 2010, 49:62-67.

17- Bartlett JG, Gilbert DN, Spellbergs B. Seven ways to preserve the miracle of antibiotics. Clinical Infectious Diseases. 2013, 56:1445-1450.

18- Nature Editorial. The antibiotic alarm. Nature. 2013, 495:141. Doi:10.1038/495141a.

19- Roberts MC. Antibiotic resistance in oral/respiratory bacteria. Crit Rev Oral Biol Med. 1998, 9:522-540.

20- Villedieu A, Diaz-Torres ML, Roberts AP, Hunt N, McNab R, Spratt DA, Wilson M, Mullany P. Genetic basis of erythromycin resistance in oral bacteria. Antimicrobial Agents and Chemotherapy. 2004, 48:2298-2301.

21- Infectious Diseases Society of America (IDSA). The 10 x 20 initiative: Pursuing a global commitment to develop 10 new antibacterial drugs by 2020. Clinical Infectious Diseases. 2010, 50:1081-1083.

22- Miró-Canturri A, Ayerbe-Algaba R, Smani Y. Drug repurposing for the treatment of bacterial and fungal infections. Frontiers in Microbiology. 2010, 10:14. Doi:

10.3389 / imicb.2019.00041.

23- Feng X, Zhu W, Schurig-Briccio LA, Lindert S, Shoen C, Hitchings R, Li J, et al. Antiinfectives targeting enzymes and the proton motive force. PNAS, 2015:E7073-E7082. Www.pnas.org/cgi/doi/10.1073/pnas.1521988112.

24- EI Arbi M, Théolier J, Pigeon P, Jellali K, Trigui F, Top S, Aifa S, Fliss I, Jaouen G, Hammami R. Antibacterial properties and mode of action of new triaryl butane citrate compounds. European J Medicinal Chemistry. 2014, 76:408-413.

25- Hussein MH, Schneider EK, Elliott AG, Han M, Reyes-Ortega F, Morris F, Blastovich MA, et al. From breast cancer to antimicrobial: Combating extremely resistant Gram-negative"superbugs" using novel combinations of polymyxin B with selective estrogen receptor modulators. Microb Drug Resist. 2017, 23:640-650. 
26- Saeidi Z, Ashjaran A. Study of anti-cancer drug release (tamoxifen) of the nanofibers made of poly-caprolactone-chitosan. International J Advanced Biotechnology and Research. 2016, 7:897-906.

27- Zorgani AA, Belgasim Z, Ziglam H, Ghenghesh KS. Antimicrobial susceptibility profiles of Gram-negative Bacilli and Gram-positive cocci isolated from cancer patients in Libya. Archives of Clinical Microbiology. 2012, 3:1-8.

28- Delcour AH. Outer membrane permeability and antibiotic resistance. Biochim Biophys Acta. 2009, 1794:808-816.

29- Luxo C, Jurado AS, Madeira VM, Silva MT. Tamoxifen induces ultrastructural alterations in membranes of Bacillus stearothermophilus. Toxicology in Vitro. 2003, 17:623628.

30- Steinbuch KB, Fridman M. Mechanisms of resistance to membrane-disrupting antibiotics in Gram-positive and Gram-negative bacteria. Med Chem Comm. 2016, 7:86-102. 31- Tripathi PC, Gajbhiye SR, Agrawal GN. Clinical and antimicrobial profile of Acinetobacter spp.: An emerging nosocomial superbug. Adv Biomed Res. 2014, 3: 13. Doi: $10.4103 / 2277-9175.124642$.

32- $\quad$ Dimple R, Nupur S, Mahawal BS, Ankit K, Ajay P. Speciation and antibiotic resistance pattern of Acinetobacter species in a tertiary care hospital in Uttarakhand. International J Medical Research \& Health Sciences. 2016, 5:89-96.

33- Kumari M, Batra P, Malhotra R, Mathur P. A 5-year surveillance on antimicrobial resistance of Acinetobacter isolates at a level-1 trauma center of India. J Lab Physicians. 2019, 11:34-38.

34- Kittinger C, Kirschner A, Lipp M, Baumert R, Mascher F, Farnleitner AH, Zarfel GE. Antibiotic resistance of Acinetobacter spp. isolates from the river Danube: Susceptibility stays high. International J Environmental Research and Public Health. 2018, 15:1-8. Doi:10.3390/ijerph15010052.

35- $\quad$ Espinal P, Roca I, Vila J. Clinical impact and molecular basis of antimicrobial resistance in non-baumannii Acinetobacter. Future Microbiol. 2011, 6:495-511.

36- $\quad$ Poirel L, Madec JY, Lupo A, Schink AK, Kieffer N, Nordmann P, Schwarz S. Antimicrobial resistance in Escherichia coli. Microbiol Spectr. 2018, 6: Doi: 10.1128/microbiolspec.ARBA-0026-2017.

37- Sáenz Y, Briñas L, Domínguez E, Ruiz J, Zarazaga M, Vila J, Torres C. Mechanisms of resistance in multiple-antibiotic-resistant Escherichia coli strains of human, animal, and food origin. Antimicrobial Agents and Chemotherapy. 2004, 48:3996-4001.

38- Olorunmola FO, Kolawole DO, Lamikanra A. Antibiotic resistance and virulence properties in Escherichia coli strains from cases of urinary tract infections. Afr J Infect Dis. 2013, 7:1

39- Annavajhala MK, Gomez-Simmonds A, Uhlemann A. Multidrug-resistant Enterobacter cloacae complex emerging as a global, diversifying threat. Frontiers in Microbiology. 2019, 10:1-8.

40- Uzunović S, Ibrahimagić A, Bedenić B. Antibiotic resistance in Enterobacter cloacae strains with derepressed/partly derepressed/inducible AmpC and extended-spectrum betalactamases in Zenica-Doboj Canton, Bosnia and Herzegovina. Med Glas (Zenica). 2018, 15:37-45.

41- Lima TB, Silva ON, de Almeida KC, Ribeiro SM, Motta D, Maria-Neto S, Lara MB, et al. Antibiotic combinations for controlling colistin-resistant Enterobacter cloacae. J Antibiotics. 2017, 70:122-129.

42- John JF, Jr Sharbaugh RJ, Bannister ER. Enterobacter cloacae: Bacteremia, epidemiology, and antibiotic resistance. Reviews of Infectious Diseases. 1982, 4:13-28. 
43- Khaertynov KS, Anokhin VA, Rizvanov AA, Davidyuk YD, Semyenova DR, Lubin SA, Skvortsova NN. Virulence factors and antibiotic resistance of Klebsiella pneumoniae strains isolated from neonates with sepsis. Frontiers in Microbiology. 2018, 5:1-9.

44- Garbati MA, Godhair AI. The growth resistance of Klebsiella pneumoniae: the need to expand our antibiogram: Case report and review of the literature. Afr J Infect Dis. 2013, 7:8-10.

45- $\quad$ Sanchez GV, Master RN, Clark RB, Fyyaz M, Duvvuri P, Ekta G, Bordon J. Klebsiella pneumoniae antimicrobial drug resistance, United States, 1998-2010. Emerging Infectious Diseases. 2013, 19:133-36.

46- $\quad$ Kidd TJ, Mills G, Sá-Pessoa J, Dumigan A, Frank CG, Insua JL, Ingram R, Hobley L, Bengoechea JA. A Klebsiella pneumoniae antibiotic resistance mechanism that subdues hos defenses and promotes virulence. EMBO Molecular Medicine. 2017, 9:430-447.

47- $\quad$ Madison G, Golamari R, Bhattacharya P. Endocarditis caused by Abiotrophia and Granulicatella species. Advanced Concepts in Endocarditis, edited by Michael S.

Firstenberg, IntechOpen. 2018:41-58. DOI: 10.5772/intechopen.74252.

48- Cargill JS, Scott KS, Gascoyne-Binzi D, Sandoe JA. Granulicatella infection:

diagnosis and management. J Medical Microbiology. 2012, 61:755-761

49- $\quad$ Alberti MO, Hindler JA, Humphries RM. Antimicrobial susceptibility of Abiotrophia defectiva, Granulicatella adiacens, and Granulicatella elegans. Antimicrobial Agents and Chemotherapy. 2016, 60:1411-1420.

50- Kanamoto T, Terakubo S, Nakashima H. Antimicrobial susceptibility of oral isolates of Abiotrophia and Granulicatella according to the consensus guidelines for fastidious bacteria. Medicines. 2018, 5:1-9. Doi:10.3390/medicines5040129.

51- Zheng X, Freeman AF, Villafranca J, Shotridge D, Beyer J, Kabat W, Dembkowski

$\mathrm{K}$, Shulman ST. Antimicrobial susceptibility of invasive pediatric Abiotrophia and Granulicatella isolates. J Clinical Microbiology. 2004, 42:4323-4326.

52- $\quad$ Moreno MG, Wang L, De Masi M, Winkler T, Trampuz A, Di Luca M. In vitro antimicrobial activity against Abiotrophia defectiva and Granulicatella elegans biofilms. J Antimicrobial Chemotherapy. 2019, 74:2261-2268.

53- Savini V, Catavitello C, Masciarelli G, Astolfi D, Balbinot A, Bianco A, Febbo F, D'Amario C, D'Antonio D. Drug sensitivity and clinical impact of members of the genus Kocuria. J Medical Microbiology. 2010, 59:1395-1402.

54- $\quad$ Purty S, Saranathan R, Prashanth K, Narayanan K, Asir J, Devi CS, Amarnath SK. The expanding spectrum of human infections caused by Kocuria species: a case report and literature review. Emerging Microbes and Infections. 2013, 2:1-8. Doi:10.1038/emi.2013.71. 55- Dave VP, Joseph J, Pathengay A, Pappuru R. Clinical presentations, management outcomes, and diagnostic dilemma in Kocuria endophthalmitis. J Ophthalmic Inflammation and Infection. 2018, 8:1-7. https://doi.org/10.1186/s12348-018-0163-6.

56- Lakshmikantha M, Devki V, Yogesh C. Is Kocuria kristinae an upcoming pathogen?. International J Current Microbiology and Applied Sciences. 2015, 4:885-889.

57- Tewar R, Dudeja M, Das AK, Nandy S. Kocuria kristinae in catheter associated urinary tract infection: A case report. J Clinical and Diagnostic Research. 2013, 7:1692-1693. 58- Tsai C, Su S, Cheng Y, Chou Y, Tsai T, Lieu A. Kocuria varians infection associated with brain abscess: A case report. BMC Infectious Diseases. 2010, 10:1-4.

http://www.biomedcentral.com/1471-2334/10/102.

59- Meletis G, Gogou V, Palamouti M, Spiropoulos P, Xanthopoulou K, Tantou P, Rizou A, Thomoglou V. Catheter-related relapsing peritonitis due to Kocuria varians in a patient undergoing continous ambulatory peritoneal dialysis. Nefrologia. 2012, 32:541-542. 
Table 1: The minimum inhibitory concentration (MIC) of TAM in Gram-positive bacteria

\begin{tabular}{|l|l|l|l|}
\hline No. & Bacteria & MIC value $\mathbf{( m g / m I )}$ & M BC \\
\hline 1 & Dermacoccus nishinomiyaensis & 0.625 & - \\
\hline 2 & Gemella sanguinis & 0.625 & + \\
\hline 3 & Granulicatella adiacens & 0.625 & - \\
\hline 4 & Granulicatella elegans & $\mathrm{R}$ & + \\
\hline 5 & Helcococcus kunzii & 0.625 & $\mathrm{R}$ \\
\hline 6 & Kocuria kristinae & 1.25 & + \\
\hline 7 & Kocuria rosea & $\mathrm{R}$ & + \\
\hline 8 & Kocuria varians & 2.5 & + \\
\hline 9 & Kytococcus sedentarius & 0.625 & - \\
\hline 10 & Leuconostoc mesenteroides ssp. cremoris & 0.625 & - \\
\hline 11 & Staphylococcus aureus & 0.625 & + \\
\hline 12 & Staphylococcus pseudintermedius & 0.625 & + \\
\hline 13 & Staphylococcus warneri & & + \\
\hline
\end{tabular}

All tested bacteria were sensitive to $1-2 \mu \mathrm{g} / \mathrm{ml}$ cefotaxime

Table 2: The minimum inhibitory concentration (MIC) of TAM in Gram-negative bacteria

\begin{tabular}{|l|l|l|l|}
\hline No. & Bacteria & MIC value $\mathbf{( m g / m l )}$ & MBC \\
\hline 1 & Acinetobacter haemolyticus & $\mathrm{R}$ & + \\
\hline 2 & Aeromonas salmonicida & 1.25 & + \\
\hline 3 & Burkhol eria cepacia & 0.625 & - \\
\hline 4 & E. coli & $\mathrm{R}$ & + \\
\hline 5 & Enterobacter cloacae complex & $\mathrm{R}$ & + \\
\hline 6 & Klebsiella pneumoniae ssp. pneumoniae & $\mathrm{R}$ & + \\
\hline 7 & Pseudomonas fluorescens & 1.25 & - \\
\hline 8 & Pseudomonas stutzeri & 2.5 & - \\
\hline 9 & Ralstonia insidiosa & 0.625 & + \\
\hline 10 & Sphingomonas paucimobilis & 0.625 & + \\
\hline
\end{tabular}

All tested bacteria were sensitive to $1-2 \mu \mathrm{g} / \mathrm{ml}$ cefotaxime 